\title{
El pensamiento estocástico: entorno indispensable en la enseñanza de la estadística inferencial
}

\author{
Walz, María Florencia ${ }^{1}$
}

\section{Resumen}

En este artículo se relata una experiencia de enseñanza de la Estadística Inferencial que tuvo como objetivo contribuir al conocimiento significativo de ésta área temática; especialmente, el de los Test de hipótesis paramétricos. La misma fue llevada a cabo en un curso de Estadística de posgrado para profesionales de la salud. Se basó en intervenciones dialécticas que priorizaban el uso de la psicología del pensamiento probabilístico en problemas reales y en el empleo de simulaciones (estrategia didáctica destinada a evitar la incomprensión del tema por posibles obstáculos epistemológicos previos). Los resultados obtenidos dan cuenta de mejoras en el aprendizaje significativo del tema objetivo; aclarándose que las conclusiones obtenidas no son inferibles a contextos generales por tratarse de una experiencia particular que podría enmarcarse en un estudio no controlado.

Palabras clave: didáctica de la estadística, aprendizaje significativo, estadística inferencial

\section{Summary}

In this article a teaching experience of Inferential Statistics is described, which aimed was to contribute to significant knowledge of this subject area; especially the parametric test. It was carried out in a graduate statistics course for health professionals. It was based on dialectical interventions which prioritized the use of probabilistic thinking in real problems and in the use of simulations (didactic strategy to avoid epistemological obstacles). The results obtained show significant improvements in learning the target area; clarifying that the conclusions are not inferable to general contexts because it is a unique experience that could be framed in an uncontrolled study.

Keywords: statistical teaching, meaningful learning, inferential statistics

\footnotetext{
${ }^{1}$ Facultad de Bioquímica y Ciencias Biológicas, Universidad Nacional del Litoral. Facultad de Ciencia y Tecnología, Universidad Autónoma de Entre Ríos.

florencia.walz@gmail.com
} 